\title{
Four decades of engaging customers in product innovation
}

Mai Khanh TRAN

Birmingham Business School, University of Birmingham

\section{INTRODUCTION}

Over the past four decades, various attempts to expand the innovation theory have engendered a sea change in this domain of research. With an ongoing focus on co-innovation for value creation, a wide-ranging analysis has been developed to reconceptualize this synchronous and interactive activity (Ramirez, 1999) and highlight the roles of various players in the process. Whilst co-innovation involves a range of actors, much research has emphasized the importance of customers in this collaboration due to their pivotal inputs in the organizations' innovation process (O’Hern and Rindfleisch, 2010).

Aligning with the development of innovation history, customers have transformed from passive buyers to value co-creators who contribute distinct values for new product development (NPD). A primary role of customers is recorded in 82 per cent of major functional improvements in scientific instruments, 85 per cent of major pultrusion-processing machinery innovation, and 100 per cent of first of type used commercially in semiconductor or electronic process equipment (Von Hippel et al., 1999). These examples are, indeed, only representing a part of the potential of customer value co-creation as they mainly reflect the operant resources from which values emerge (O’Shaughnessy and O'Shaughnessy, 2011, 2009). Going beyond a focus on instrumentality, it should be noted that the meaning of value cocreation may vary when being examined from different approaches. Specifically, the sociocultural understanding suggests that values can be seen as idiosyncratic, experiential, contextual, and meaning laden (Vargo and Lusch, 2008; Peñaloza and Venkatesh, 2006). To account for more complex value-creation scenarios, it is also important to eliminate the producer-consumer dichotomy to see how customers can play new and more active roles, what other types of values they can contribute to the NPD, and how to assist them in value cocreation process. 
It can be seen that customer co-creation is not a nascent research area, yet it has been little studied in innovation literature. Therefore, it is timely to re-examine the state of customer collaboration in NPD theory. The following questions are of interest of this chapter:

1. How does customer co-creation align with the evolution of innovation theory?

2. What are the roles of customers in co-innovation?

3. What values can customers contribute, especially from a socio-cultural approach?

4. How should customers be identified and profiled for value co-creation purposes?

By answering these questions, this chapter offers comprehensible understandings of the competences of customers in co-innovation and value co-creation. Not only is it a tribute to research in innovation theory, this chapter is also expected to inspire future research and create new modes of research on NPD and value creation theory. The chapter is structured as follows: it begins with a description of the methodology to explain how the data have been studied. Then, the results section comprises a discussion and examination of the four research streams to respond to the four research questions. Suggestions and prospects for future research will conclude the chapter.

\section{METHODOLOGY}

Since the discussion and the contribution of the chapter are based on the development of customer co-creation theory in scholarly NPD research over time, the method employed in this chapter is content analysis corroborated by case studies.

Content analysis has been used in examining the growth and devel- opment of NPD literature by many authors such as Baregheh et al. (2009) or Page and Schirr (2008). Having been employed as a systematic and objective means of describing and quantifying content in terms of predetermined categories (Bryman, 2001; Sandelowski, 1995; Downe- Wamboldt 1992; Krippendorff, 1980), content analysis is a powerful data reduction technique and a useful tool when dealing with large volumes of data. Extending far beyond simple word counts (Stemler, 2001), the technique is based on explicit rules of coding to allow researchers to compress words into fewer content categories, which are groups of words 'with similar meaning or connotations' (Weber, 1990: 37). Content categories also enable researchers to describe the phenomenon to increase understanding and generate knowledge (Cavanagh, 1997). 
Hence, this technique is used to objectively and systematically identify specified characteristics of messages to make inferences (Krippendorff, 1980). Content analysis, according to DowneWamboldt (1992), is concerned with meanings, intentions, consequences and context. As a result, not only does it sift through large volumes of data with relative ease in a systematic fashion (U.S. General Accounting Office, 1996) but it also provides knowledge through making replicable and valid inferences from data to their context, examining trends and patterns in documents. Moreover, it is a useful tool to analyse documents as well as offering new insights, representation of facts, and practical guidance for action.

In this chapter, a two-phase research approach was employed. The first phase is the identification of published papers. The chosen period started from 1976, in which customer cocreation concept first appeared in academic journal, to the middle of 2015. This led to 588 articles in the English language found through various sources such as Google Scholar, Science

Direct, EBSCO, Proquest, Reference lists of NPD-related text books, NPD review articles, and search within NPD journals and related NPD journals. Leading journals such as Journal of Product Innovation Management, Creativity and Innovation Management, European Journal of Innovation Management, and Journal of Business Research were heavily prioritized. A compilation of keywords has been used in search in this study, such as NPD, co-innovation, customer co-creation, customer values, customer engagement, symbolic value, and experiential consumption. In the second phase, the articles were classified by streams and topics of research in accordance with the four research questions raised in the introduction. By conducting content analysis with an objective coding scheme, the data were condensed, made to be systematically comparable (Berg, 2004), and studied to discern the trends of research over time. A literature review and case studies were used to supplement the analysis where pertinent to better illuminate the phenomenon.

\section{THE DEVELOPMENT OF CUSTOMER COLLABORATION IN CO-INNOVATION}

\section{An Evolution from Innovation 1.0 to Innovation 4.0}

Innovation started to strengthen its central role in marketing in the early 1950 s and has continued to prove its role as a core renewal process in any organization (Adams et al., 2006). 
Over the past decades, innovation has moved from the 'Innovation 1.0: closed innovation' stage to the 'Innovation 4.0: co-innovation' stage in which values are created collaboratively with various stakeholders within industry sectors (Lee et al., 2012). Whilst there are some actors owning more privileges than others in defining and regulating values, the involvement of customers in value co-creation has become a phenomenon in product innovation theory.

To shed light on how the customer co-creation theory is in line with the development of innovation literature, the innovation trajectory will first be introduced to set the background for further analysis. The evolution started with the closed innovation stage when organizations developed unique competencies internally. At this stage, the critical source of innovation came from the R\&D department, the collaboration only occurred among employee networks (Whelan et al., 2011), and the value chain of the organization was created as independent. The firms operated 'under a complete secret to the outside world' (Lee et al., 2012: 822) to produce competitive advantage that would allow them to be the first mover to the market. Some of the most popular closed innovation systems at Innovation 1.0 would be the Bell Labs, R\&D Department of Procter \& Gamble (P\&G), and NASA. The search for external alliances started when the firms entered the stage of 'Innovation 2.0: collaborative innovation'. At this stage, firms conducted many new forms of partnerships, strategic alliances, joint ventures, technology sharing arrangement, and inter-organizational relationships. Some leading business organizations that followed this mind-set to develop their sustained competitive advantage are Nike, Apple, Mattel and Dell, to name but a few. With the development of information and communications technology and the networked global economy, innovative firms extended their collaboration for innovation. By engaging different intra-firm units, the concept of 'openinnovation' was coined to describe the third stage of innovation (Chesbrough, 2003). Becoming more widely employed in the early 2000s, the open-innovation model incorporated customers into its process besides continuing to develop a creative convergence of the firms' competence with expertise from external sources. $P \& G$ and NASA also moved towards the open-innovation model, together with Microsoft, LG, NineSigma and InnoCentive (Lee et al., 2012; Lichtenthaler et al., 2011). The innovation history continued with Innovation 4.0 in the early 2010s. In the era of co-innovation, firms started both to generate new ideas from various sources and to create new types of value for stakeholders, including experiences and transformation, known as the highest offerings in the progression of economic values (Pine and Gilmore, 1999). In this scenario, the contribution from customers is further highlighted and the 
need to monitor customer value co-creation has increasingly received critical attention (Lee et al., 2012).

The evolution of innovation theory has informed the development of customer co-creation as an emerging research area. From the timescale, customer role in co-innovation started to earn considerable recognition in the early 2000s and achieved extraordinary growth since 2011. Accordingly, the data from this content analysis will be examined in three time periods. The first one is from 1976 to 2000, when customer involvement was found to be relatively ambiguous in the innovation process. This is the longest period of time in the trajectory of customer co-creation theory development, yet has the smallest number of scholarly works. Including the first article introducing customer co-creation concept in NPD in 1976 by Rothwell, there are only 12 scholarly articles published during these 25 years. The second period lasted from 2001 to 2010, when the literature of customer co-creation was more advanced. Within these 10 years, the number of research works was five times greater than that in the first period. However, the clearest upward direction of article distribution is shown in the third period, between 2011 and 2015. In five years, more than 500 articles about customer co-creation have been published, which illustrates a significant growth over a very short period of time when compared to the previous phases. Figure 5.1 represents the development of customer co-creation theory in the NPD literature.

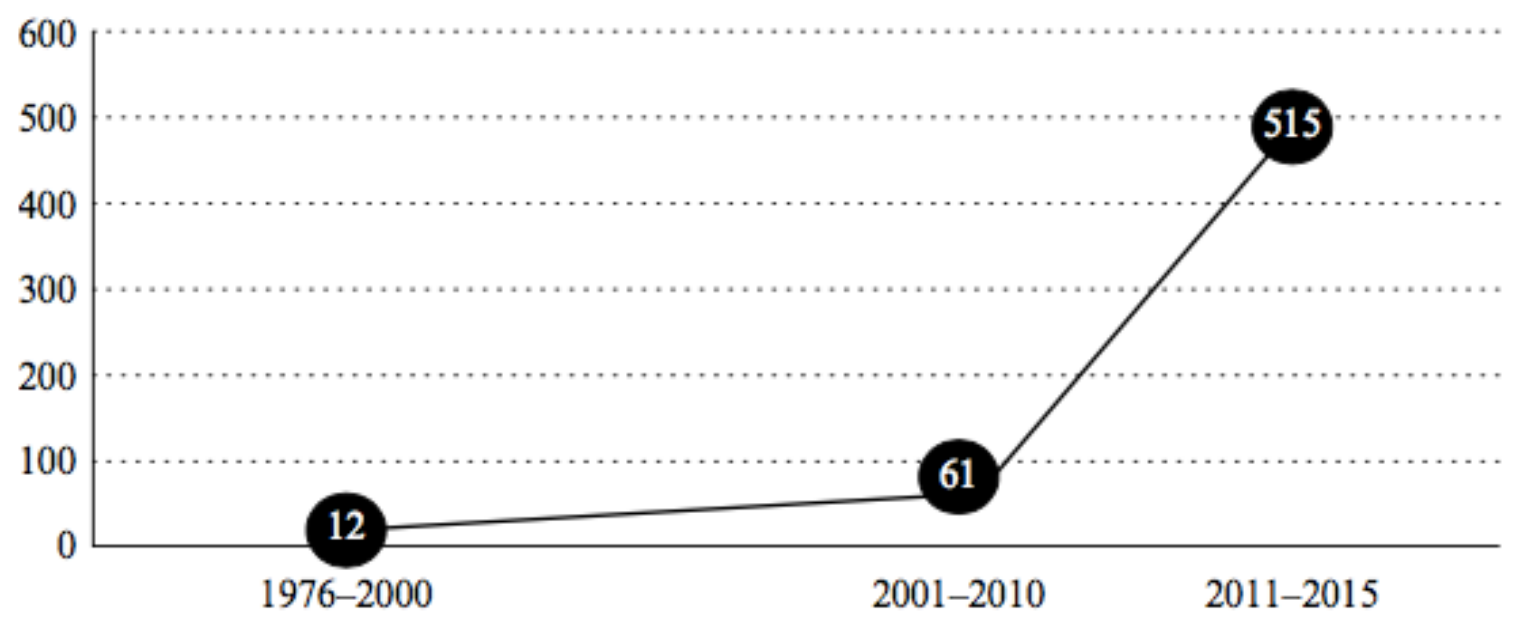

Figure 5.1: Number of articles related to customer co-creation in NPD, published between 1976 and 2015 Source: The author 
A remarkable number of publications found in the 2000s and their findings in this phase further contended that customer co-creation has become a powerful and general phenomenon in NPD. However, this record should be seen as the result of the whole process of theory development. To better illuminate the paradigm shift towards the customer-centric approach in NPD, a summary of the development of customer roles across time is presented in Table 5.1. By dividing the whole research period into four quartiles, each of which is assigned an equal length of 10 years, the table is aimed to provide a clearer picture of how customers have transformed from passive users to active players over the last few decades.

The first transition which can be clearly observed is the communication between businesses and their customers when the one-way communication in the 1970s was switched to a more interactive communication in the next decades. From the table, it can also be seen that firms started gaining market knowledge from their existing customers in the 1980s to redesign products and identify problems of offerings ( $\mathrm{Li}$ and Calantone, 1998). In addition, more customer services were developed within this second quartile such as the help desk, call centre, and customer service programmes. However, it was not until the 1990s that firms started to create stronger bonds and relationship with customers. Businesses started recognizing the power of different customers, which led to the very first categorization of 'lead user' (which will be discussed in greater detail in section 6 of this chapter). These activities have accumulatively built up the foundation for a strong customer co-creation phenomenon in the 2000 s.

\section{The Growing Importance of the Customer-centric Approach}

The role of customers in value co-creation has specifically gained increased attention from marketing scholars (Vargo and Lusch, 2004) for three reasons: the primary role of customers in developing new products in various industries, the intensity of their contributions in NPD processes, and their critical roles in successful innovation diffusion.

First, customer co-creation can be found in a wide variety of industries, from scientific instruments to entertainment. In the automotive industry, an innovation called Infotainment System, which integrated communication and entertainment technologies, was initially developed by Audi's customers. It was created after customers used toolkits provided by Audi to propose their own ideas for a new and improved infotainment device (Füller et al., 2006). 


\begin{tabular}{|c|c|c|c|c|}
\hline & $\begin{array}{l}1970 \mathrm{~s} \text { and } \\
\text { early } 1980 \mathrm{~s}\end{array}$ & $\begin{array}{l}\text { Late } 1980 \mathrm{~s} \text { and } \\
\text { early } 1990 \mathrm{~s}\end{array}$ & $1990 \mathrm{~s}$ & Beyond 2000 \\
\hline Context & $\begin{array}{l}\text { - One-way } \\
\text { communi- } \\
\text { cation } \\
\text { - Products } \\
\text { and services } \\
\text { are created } \\
\text { without } \\
\text { much } \\
\text { feedback }\end{array}$ & $\begin{array}{l}\text { - Two-way } \\
\text { communication } \\
\text { - Database } \\
\text { marketing } \\
\text { - Company shifts } \\
\text { from selling to } \\
\text { helping } \\
\text { (via help desks, } \\
\text { call centres, } \\
\text { and customer } \\
\text { service } \\
\text { programmes) }\end{array}$ & $\begin{array}{l}\text { Two-way } \\
\text { communi- } \\
\text { cation and } \\
\text { access } \\
\text { - Relationship } \\
\text { marketing } \\
\text { - Deep } \\
\text { understanding } \\
\text { of customers } \\
\text { to reconfigure } \\
\text { products }\end{array}$ & $\begin{array}{l}\text { - Multilevel } \\
\text { access and } \\
\text { communication } \\
\text { - Active dialogue } \\
\text { with customers } \\
\text { to shape } \\
\text { expectations and } \\
\text { create buzz } \\
\text { - Experiential } \\
\text { values are more } \\
\text { prioritized }\end{array}$ \\
\hline $\begin{array}{l}\text { Roles of } \\
\text { customers }\end{array}$ & $\begin{array}{l}\text { - The } \\
\text { customer is } \\
\text { an average } \\
\text { statistic } \\
\text { - The } \\
\text { customers } \\
\text { are groups } \\
\text { of buyers } \\
\text { predeter- } \\
\text { mined } \\
\text { by the } \\
\text { company }\end{array}$ & $\begin{array}{l}\text { - The customer } \\
\text { is an individual } \\
\text { statistic in a } \\
\text { transaction } \\
\text { - Customers } \\
\text { identify } \\
\text { problems, } \\
\text { provide } \\
\text { feedback to } \\
\text { help redesign } \\
\text { products and } \\
\text { services are }\end{array}$ & $\begin{array}{l}\text { - Customers are } \\
\text { the target of } \\
\text { the creation of } \\
\text { lifetime bonds } \\
\text { - Customers/ } \\
\text { users are } \\
\text { observed } \\
\text { to identify } \\
\text { their needs, } \\
\text { from which } \\
\text { firms provide } \\
\text { offerings } \\
\text { - Lead users are } \\
\text { recruited } \\
\text { to identify } \\
\text { solutions }\end{array}$ & $\begin{array}{l}\text { - The customer } \\
\text { is both an } \\
\text { individual and } \\
\text { part of social- } \\
\text { cultural context } \\
\text { - Customers are } \\
\text { co-designer, } \\
\text { co-brander, } \\
\text { co-marketer, } \\
\text { co-producer } \\
\text { - Customers are } \\
\text { developers of } \\
\text { personalized } \\
\text { experiences } \\
\text { - Customers } \\
\text { have joint roles } \\
\text { with companies } \\
\text { in shaping } \\
\text { expectations } \\
\text { and co-creating } \\
\text { market } \\
\text { acceptance }\end{array}$ \\
\hline Summary & $\begin{array}{l}\text { Customers } \\
\text { are pre- } \\
\text { determined } \\
\text { groups of } \\
\text { buyers }\end{array}$ & $\begin{array}{l}\text { Customers are } \\
\text { individual } \\
\text { buyers in a } \\
\text { transaction }\end{array}$ & $\begin{array}{l}\text { Customers are } \\
\text { the target of } \\
\text { relationship } \\
\text { building }\end{array}$ & $\begin{array}{l}\text { Customers are } \\
\text { co-creators of } \\
\text { values }\end{array}$ \\
\hline
\end{tabular}

Table 5.1 Changes in customer roles

Source: Adopted from Mukhtar et al. (2012: 290). 
In the sportswear industry, Nike adopted ideas from their highly ambitious and skilled basketball-shoe customers and then combined new and advanced shoe designs with lacing and cushioning technologies (Füller et al., 2007). In the entertainment industry, Harry Potter enthusiasts became the creators of new Harry Potter media products ranging from songs, to videos and entire magazines (Brown, 2007). These co-creation projects all achieved success in the marketplace, which reminds businesses of the importance of understanding and taking into account their customers' expectation of engaging in the process. Customers are increasingly expecting to have more opportunities to learn new things and maximize their experience of new products or services through such engagement.

Second, customer integration offers firms a range of benefits during the NPD process, from new ideas to a higher chance of successful innovation diffusion. Since most projects do not fail at the end but fail at the beginning (Zhang and Doll, 2001), the first stage of NPD, commonly involved in the idea generation, is the key to the success of an innovation (Khurana and Rosenthal, 1998). Whilst many markets have found forecasting demand for new products increasingly difficult, extant research has suggested that a deep integration of customers in the innovation process decreases the failure rate (Piller and Lindgens, 2011). From this perspective, not only could customers contribute in the generation and development of ideas, but they could also take part in testing and evaluating products to actively raise comments and recommendations. With the widespread adoption of Web applications, businesses can deploy social media to empower customers to co-create values by sharing experiences and knowledge with producers and among customer communities (Constantinides et al., 2015). This enables customers to provide their inputs in a number of ways, from proposing new ideas to experiencing the full NPD journey. They can also test products and provide purchase recommendations to people in their network. By getting customers involved in these all stages of an innovation process, firms can achieve the highest level in their scope of collaboration (Rowley et al., 2007).

The last reason for the critical role of customers in co-innovation lies in their power of determining the success of innovation diffusion in the marketplace. Their perceptions of innovation influence the innovation adoption, ideas, and types of values to be created. An innovation is perceived to be successful and meaningful only when it is adopted by consumers (Hetet et al., 2014). This discourse was also supported by Arts et al. (2011: 141) '...Product involvement, innovativeness, and opinion leadership, which all relate to a consumer's intrinsic 
engagement with the new product and the product category, are positively related to adoption behaviour'. Thus, the evaluation of a product or service innovation relies on how customers evaluate its attributes with certain use purposes and situations in mind (Vandecasteele and Geuens, 2010; Gardial et al., 1994). This means that the originality and novelty of an innovation may not be the only criteria to assess a new product. From this perspective, the notions of innovation are also challenged and extended significantly. If extant research showed that customers mainly look for greater functional values or technology advances of new product offers (Darroch and McNaughton, 2002), more recent research has found that the innovation adoption behaviours rely on a number of socio-cultural factors, including positive societal impact and experiential values (Tran and Shiu, 2015; Schweizer et al., 2014; Garcia and Calantone, 2011).

\section{ROLES OF CUSTOMERS IN CO-INNOVATION}

Whilst the traditional approach assigns customers as passive buyers, the new perspective recognizes the complex reality of value creation scenarios and sees customers as active contributors (O'Hern and Rindfleisch, 2010). The concept of customers as co-creators has become a popular keyword since the early 2000s and can be found in more than 100 articles as generated from the content analysis (Table 5.2). To better demonstrate the roles of customers in NPD, this section will examine customers as co-innovators, co-marketers and co-branders, socially responsible actors, and co-designers. Some restricted areas of customer co-creation will also be discussed.

\section{Customers as Co-innovators}

Customers as co-innovators started being used in the early 2000s and became more popular from 2007. This terminology can be found in studies on innovation and organization, changing roles of customers, or alternative logics for innovation (Dey, 2010; Mele et al., 2009; Graf, 2007; Wijnberg, 2004). Instead of deducing customers' desires, this notion prioritizes the guidance and provision of toolkits to help customers design and develop their own products in the form of modelling or prototyping (Thomke and Von Hippel, 2002). 


\begin{tabular}{lcc}
\hline Roles of customers & Number & $\%$ \\
\hline Co-creator & 105 & 46.05 \\
Co-innovator & 51 & 22.37 \\
Co-marketer and co-brander & 24 & 10.53 \\
Socially responsible actor & 12 & 5.26 \\
Co-designer & 16 & 7.02 \\
Others & 20 & 8.77 \\
\hline
\end{tabular}

Table 5.2 Number of articles explaining roles of customers in NPD from 2010 to 2015

Source: The author.

By engaging in all innovation activities, customers are enabled to seek positive impact of a new product, experience different degrees of innovativeness, enhance product effectiveness, and suggest ideas that are even 'more original . . . than the professional developers did' (Magnusson, 2003: 235). In this context, knowledge from customers must be combined with internal sources by traditional R\&D to respond to customers' changing needs on an individual level (Romero and Molina, 2011). Therefore, this notion encourages firms to provide guidance to their customers to uncover tacit and latent needs that have not been considered previously. This will drive them to concoct new products and services that can satisfy the target market (Schubert and Ginsburg, 2000).

\section{Customers as Co-marketers and Co-branders}

The concept of co-marketers/ co-branders was coined in the late 1990s and became more popular since 2010. It can be found in scholarly works aimed at developing customer-integrated business models, examining motivators and inhibitors for tailored co-creators, and understanding implications of social media in user communities (Zare Bidaki, 2015; Dash, 2013; Loic et al., 2010). As suggested by Muniz and O'Guinn (2001), the brand is the experience and the experience is the brand; firms should recognize the importance of providing their customers with knowledge, tools and resources to enable them to share their own experiences. By giving customers a new role as co-marketers or co-branders, firms are developing their new perspectives including a focus on customer-generated content. This, in turn, allows them to spread reputation, support customers, and discover the hidden behaviour of customers. Apprehending the evolution of social networks and interactive websites, firms are better equipped to provide an interactive environment amongst customers and between customers and companies. This will also be helpful for businesses to understand customers' demands and types of marketing communication messages that can bring trust to audiences, 
which benefits marketing and branding activities (Armstrong and Hegel, 1997). Giving customers the opportunity to participate, therefore, enables businesses to have better insight into their customers and empowers them to have a greater voice, which consequently creates experience and positive effects in brand equity.

\section{Customers as Socially Responsible Actors}

This notion is based on the philosophy of social responsibility according to which all actors in society will 'take the responsibility for the impact of their activities . . . in the environment in all aspects of their daily life' (Romero and Molina, 2011: 451). As described by Aburdene (2005), the buying behaviour of these socially responsible actors/customers is influenced by the way firms exercise their corporate social activities. Customers, in this context, are described as belonging to a new generation that acts consciously and believes in a healthy lifestyle and sustainable development. Conscious customers, with the assistance of social com- munities, can form their own network and involve themselves in the NPD process, of which the essence is the shared understanding about the commitment to the creation of sustainable value. The cocreation between customers and firms results in a set of duties and responsibilities which are critical for building up corporate social responsibility programmes and ensuring wealth for all stakeholders in the business ecosystem.

\section{Customers as Co-designers}

This notion stems from the nature of participation of customers in the NPD process. Not only do they test an existing product, customers are also expected to be involved in generating new concepts, designing products and services in the market (Foray, 2004) and voluntarily sharing their ideas and experiences (Romero and Molina, 2011). This allows both parties to reach a point of free exchange where customers are motivated to engage in the ideation and concept development stage, from which they can get involved 'directly in the co-creation of value, ... at any stage of the value chain' (ibid.:405). Engaging customers as co-designers has been addressed in research on product design (Pals et al., 2008), fuzzy front-end models (Zhang and Doll, 2001), and interactions on virtual environments (Nambisan and Baron, 2007). Von Krogh (2006) analysed three advantages of empowering customers as co-designers in co-innovation, namely gaining deeper insight into customers' behaviour and preferences, reducing the cost of framing new ideas, and enhancing their loyalty. When inviting customers as co-designers, there are a few crucial points that firms need to take into account. In particular, the intellectual 
property rights and rewards scheme must be considered carefully and thoroughly to avoid causing dissatisfied customers or public battles.

\section{Restricted Roles of Customers in the Arts}

By perceiving customers as co-designers, co-branders, co-innovators, or socially responsible actors, firms are offering greater opportunities to collaborate with customers and to turn their competencies and knowledge into business competitive advantages. However, there is an exception to this role in the arts industry, in which customers cannot be involved as the codesigners of any art form. This issue has received great attention as 'the arts' covers a wide range of activities and formats, as defined by the Arts Council of Great Britain (ACGB) in 1993:

The term 'the arts' includes, but is not limited to, music . . ., dance, drama, folk art, creative writing, architecture and allied fields, painting, sculpture, photography, graphic and craft arts, industrial design, costume and fashion design, motion pictures, television, radio, tape and sound recording, the arts related to presentation, performance, execution and exhibition of such major arts forms, and the study and application of the arts to the human environment.

The art itself has a distinctive process, in which aesthetic languages are broken down and recreated to create new aesthetic metaphors. Boorsma (2006: 85) explained that the metaphors are only new if they are created by artists without any generalization of 'what is thought by potential customers' and what they 'want to see or hear'; otherwise, the outcome will lose its originality and will be perceived as 'an embellishment of something that already exists'. Therefore, arts organizations need to ensure 'a certain level of artistic freedom on the part of the artist' and keep arts customers and audiences from being 'actively involved before the artistic idea has developed its form' (Boorsma, 2006: 85). From extant research, customers can only perform the co-creator role in the final stage of the art process when they are called the co-producers of meanings. This means they will use their imaginative powers to give meaning to the artefact, which is independent of existing concepts and external interests. As meaning making is a central role in the final stage of arts consumption, arts organizations need to give their customers adequate assistance and reinforcement through continuous interaction and iterative learning processes. In the cultural consumption context, the support of building up communicative skills and developing appropriate attitudes has become a crucial task. 


\section{TYPES OF CUSTOMER VALUE AND A SHIFT TOWARDS A SOCIO-CULTURAL APPROACH}

\section{Types of Customer Value}

Customer value is defined as 'a customer's perceived preference for, and evaluation of, ... product attributes, attributes of performances, and consequences arising from use that facilitates or blocks [them from] achieving ... goals and purposes in use situations' (Woodruff, 1997: 141).

A comprehensive approach explains this concept as 'an interactive relativistic preference and experience' (Holbrook, 2005: 46) which is perceived uniquely by individual customers (Ulaga, 2003). Customer value is also "what customers get (benefits, quality, worth, utility) from the purchase and use of the product versus what they pay (price, cost, sacrifices), resulting in an attitude toward or an emotional bond with the product' (Smith and Colgate, 2007: 8). An understanding of customer value is important as the principle of marketing and NPD activities lies in how to create values that are 'superior to the ones offered by the competition' (Boorsma, 2006: 77) and deliver values that customers need and want.

Extant literature has introduced a number of frameworks of customer value. The earliest framework created in 1986 by Park et al. was based on analysis on consumer needs, namely functional needs, symbolic needs and experiential needs. Although this framework clearly reflected value dimensions, it poorly captured the cost aspect as mentioned in the definition. Another three-factor framework was proposed by Heard in 1993 to conceptualize customer value in terms of product characteristics, delivered orders and transaction experiences. This approach, which focused on value resources, was evaluated as parsimonious since there could be a number of further sources influencing customer value, such as physical environment or symbolic/expressive value. In 1999, Holbrook introduced eight types of values based on a clear conceptual basis composed of motivation behind a value assessment, orientation of value assessment and nature of value assessment. However, this framework was criticized for inadequately capturing the domain of the customer value construct. A better version constructing customer value was introduced by Woodall in 2003 with five primary forms of value. However, a considerable overlap in these categories has made the framework difficult to use. Amongst the extant research, the most comprehensive framework so far is the one developed by Smith and Colgate (2007). Building on the strengths of previous frame- works 
and mitigating their weaknesses, Smith and Colgate (2007) focused on categories of value that could differentiate offerings rather than solely listing benefits and costs. The framework consists of four major types of value, named as: Functional (Instrumental) value, Cost (Sacrifice) value, Symbolic (Expressive) value, and Experiential (Hedonic) value.

Whilst Functional value prioritizes the degree to which a product achieves its desired characteristics, usefulness, and function, as adopted by McDonald's (fast-food chain) or Pfizer (pharmaceutical company), the Sacrifice value is concerned with transaction costs. Tactics on reducing Sacrifice value are employed differently across industries. For instance, FedEx (fast delivery service) attempts to minimize relational cost and maximize convenience, Marriott (hotelier) and Ford (automotive company) focus on reducing risks perceived by customers through guarantees, warranties or third-party endorsement. The Symbolic is concerned with psychological meaning of a product and is largely adopted by luxury brands. It focuses on consumers' self-concepts and self-worth, which means that customers feel good whilst consuming the products, either for themselves or as a gift to others. Branded products can sell well through focusing on this value, as Marc Jacobs fragrance flatters consumers in expressing their authenticity and personality through exquisite scent, or Rolex (watchmaker) creates a sense of prestige and image. Symbolic value is also becoming more popular in the fast-moving consumer goods (FMCG) industry, as Fairy (a washing-up liquid brand) has shown in its campaigns to evoke family relationships and motherly care. With respect to Experiential value, it relates to appropriate experience, feelings and emotions for the customers. Firms in various industries, from retailing, entertainment, to travel, have focused on developing this value through analysing the choices of customers on experience of usage (Boorsma, 2006). In beauty and body care, L'Occitane is one of the icons succeeding in maximizing the sensory value of store visitors. This brand is well-known for achieving the art of integrating sensory experiences by delivering both a luxurious interior design (sight) and an enticing aroma (smell) to the visitors to its stores. Not only do L'Occitane indulge their customers with the story of the ingredients from the Occitane village in France, this brand also delights store visitors with an accomplished purchase journey with rose tea, champagne and free hand treatment. In the entertainment industry, Disney has won the hearts and minds of audiences when bringing curiosity and novelty to children, not only through beautiful fairy tales, but also through new ways of seeing the world. Normal daily life becomes more adventurous through the lens of bugs (A Bug's Life), fishes (Finding Nemo), toys (Toy Story), monsters (Monsters, Inc.), or 
even feelings (Inside Out). Keeping its customers surprised with the power of make believe, Disney has brought this whole fantasy world to reality and named it Disneyland.

\begin{tabular}{|c|c|c|}
\hline Time periods & Typologies & Key aspects \\
\hline \multirow[t]{2}{*}{ 1970s-1995 } & $\begin{array}{l}\text { Utility, } \\
\text { benefit } \\
\text { Cost, prices, } \\
\text { sacrifices }\end{array}$ & $\begin{array}{l}\text { Being what customers get (benefits, quality, } \\
\text { worth, utility) from the purchase and use of } \\
\text { the product versus what they pay (cost, prices, } \\
\text { sacrifices) }\end{array}$ \\
\hline & $\begin{array}{l}\text { Emotional } \\
\text { bond }\end{array}$ & $\begin{array}{l}\text { Benefits of the products versus what they pay, } \\
\text { leading to attitude toward or emotional bond } \\
\text { with product }\end{array}$ \\
\hline \multirow[t]{4}{*}{$1996-2000$} & \multirow{4}{*}{$\begin{array}{l}\text { Perceived } \\
\text { preference } \\
\text { and } \\
\text { evaluation }\end{array}$} & Broad conceptualization: \\
\hline & & Multiple context (pre and $\mathrm{F}$ \\
\hline & & $\begin{array}{l}\text { Multiple cognitive tasks (preference for and } \\
\text { evaluation of) }\end{array}$ \\
\hline & & $\begin{array}{l}\text { Multiple assessment criteria (attributes, } \\
\text { performances, consequences) }\end{array}$ \\
\hline \multirow[t]{5}{*}{ Beyond 2000} & \multirow{5}{*}{$\begin{array}{l}\text { Preference } \\
\text { and } \\
\text { experience }\end{array}$} & Interactive, relativistic preference and experience \\
\hline & & Perceived uniquely by individual customers \\
\hline & & Conditional or contextual \\
\hline & & Relative (in comparison to known alternatives) \\
\hline & & Dynamic (changing within individuals over time) \\
\hline
\end{tabular}

Table 5.3 Key aspects of customer values across time Source: Adopted from Smith and Colgate (2007), Holbrook (2005), Ulaga (2003), Sinha and DeSarbo (1998), Parasuraman (1997), Woodruff (1997), Butz and Goodstein (1996), Gale (1994), Heard (1993), Zeithaml (1988).

\begin{abstract}
A Shift of Values
With the emerging nature of customer co-creation theory, there might be neither a commonly accepted definition of customer value nor a shared conceptualization of customer value typologies. However, it is worthwhile to see the shift paradigm of this research stream across time. Table 5.3 summarizes the findings of the content analysis to depict the state of development of this concept.
\end{abstract}

It can be seen that values created for customers have been moving from utility and costeffectiveness towards emotional bond, preference and experience. Since 1996, more attributes related to perceived preferences and evaluation of consequences from the use of products have been counted to describe the term 'customer value'. The Symbolic element and Experiential value have gained more attention of both researchers and practitioners. The two case studies 
below will explain this paradigm shift in greater detail and suggest how customer co-creation can fit in and enhance the creation of these values.

\section{From Functional value to Symbolic value}

Factors of involvement and innovativeness can be developed from the values and behaviours of customers (Arts et al., 2011) to engage them in co-creation of symbolic values for a brand. To best encapsulate this perspective and suggest how a brand can move from providing utility values to socio-cultural offerings, a case study of a Finnish brand named Reino \& Aino (Närvänen, 2013) will be re-examined from the lens of value theory. From an inactive and stagnating brand, this slipper company has become popular again through successfully evoking the association of Finnish customers with their national identity, cultural heritage, family connected- ness, socio-cultural identities, and even philosophy of their working place. Beyond that, Reino \& Aino has been successful in involving customers in sharing memories and experiences, from which they started welcoming customers in branding, marketing and manufacturing co-designed products. This process of involving customers consisted of four phases: sleeping brand, spontaneous appropriation, diffusion, and convergence, based on a strong background of Finnish pride, identity and loyalty (Närvänen, 2013).

In the first phase, Reino \& Aino only focused on utility (keeping feet warm in countryside houses) and cost value strategy. It should be noticed that whilst elderly people still wished to continue to retain a rural lifestyle, the younger generation had abandoned it. Therefore, the brand was mainly associated with the group of elderly people, especially farmers and the older generation living in the same house. In the late 1980s, the brand production was moved to Eastern Europe to keep costs down. However, sales still declined, the brand had a minor role in the company's portfolio, and marketing support was assigned to a minimum level.

The brand started its second stage when the trademark was purchased by a factory manager and a product designer in the company. With their genuine vision of creating a brand regarded as truly authentic, they moved production back to Finland and recaptured the country origin, reinforcing the brand identity as genuinely and authentically Finnish. By emphasizing national identity, it created the first association with customers and resonated in their minds. Reino \& Aino started focusing on the symbolic value of a Finnish brand with history, national identity, pride, nostalgia, tradition and ownership. Through promoting the brand's cultural heritage, Reino \& Aino attracted Finnish families to become the first group to re-adopt the brand. 
Customers started expressing their personal, emotional, nostalgic sentiment, and family connectedness, which made the brand increasingly perceived as a symbol of family love and the home. In addition to the national identity, more new meanings of the slippers were created by customers, including a remark of significant rites and passage, an analogy of family in a working environment to evoke empathy, protection and belonging of company staff. The brand was also chosen in ritualized events that signalled a transition from one status to another (Van Gennep, 1960) such as when one became a parent, or when a relationship is formed between couples or between parents and children. Reino \& Aino, in response to the market, introduced models for children and babies, which affirmed their appreciation of customers' demands and the focus on the symbolic value of gift-giving practice. Going beyond commercial interest, the slipper brand also associated itself with altruistic values by engaging in activities with Finnish charities to gain greater credibility and attract new customers. Moreover, Reino \& Aino also took an innovative step by inviting people to share their memories and experiences of the brand.

Encouraging customers to ascribe meanings and stories had, indeed, triggered word-of-mouth for Reino \& Aino's slippers in the market and helped the brand to characterize their diffusion phase. In the third phase, the slipper brand continued to expand new meanings and practices such as constructing group membership or demonstrating personal style by wearing slippers mixed and matched with clothes.

As customers of Reino \& Aino were not of any particular age or social class, the sociodemographic approach became irrelevant in analysing its market. Therefore, in a Reino \& Aino running competition, participants were not divided by gender and age. Instead, they were grouped by their slipper sizes, which started the establishment of community through adopting the brand as their symbol. Beside an intergenerational adoption, the brand continued promoting the voice of customers, from only enthusiasts to socialized customers such as a popular singer of a Finnish music band. From this foundation, cooperation with celebrities and a co-design strategy were adopted, making Reino \& Aino a favourable brand in Finland.

Since new customers emerged and sales increased, the slipper brand was able to invest in a new product design with new colours and modi- fied models. By positioning itself as a source of linking value, the brand encouraged the involvement of communities and focused on listening to and responding to the voice of customers. In this convergence phase, the core catalyst was the visible and active cooperation of Reino \& Aino's customers. This allowed a combination and convergence between brand owners and customers to ensure the authenticity 
of the brand and, simultaneously, to welcome customer involvement in the process. To achieve a community symbol, Reino \& Aino offered customized slippers together with a range of community activities including a loyal customer club and consumer groups' contests and events. The success of the brand, as explained by its owners, started when the commercial aspect was down- played and communities began emerging.

Whilst there should be no fixed model of symbolic value co-creation with customers, this case study offers a framework of how a brand can facilitate its customers in the process of sensemaking and meaning construction. It highlights the importance of encouraging customers to create new meaning for the brand through an interactive and reciprocal position. By focusing on symbolic value creation, Reino \& Aino has successfully shifted the roles of customers from traditional buyers to co-designers and co-branders, which has made its brand revitalization a success.

\section{From Functional value to Experiential value}

Beating the competition in the future will require companies to build new competence to create value through experiences together with their customers (Prahalad and Ramaswamy, 2004). This notion should first be analysed from the nature of value which can be delivered to the customers both 'in the form of tangible goods, with a fixed set of features and attributes' and 'intangible services and experiences, with high knowledge content' (Romero and Molina, 2011: 452-3). Also, the quality of the overall experiences in the customer journey becomes the locus of value co- creation, especially when it is combined with the degree of personalization to help customers reach their expected outcome. Many performing arts businesses, such as museums and art galleries, even compete for audiences and funding by offering experiences alongside traditional forms of display (Goulding and Saren, 2010). In research on integrating customer value and artistic objectives, Boorsma (2006) clearly differentiated the experiential perspective from the instrumental perspective to emphasize the importance of a dynamic interaction between customers and products in creating hedonic values. Accordingly, experiential consumption decisions are often based on holistic impressions (Holbrook and Hirschman, 1982), which analyses the choices of consumers 'on the basis of the pleasure, hedonistic fulfilment, emotional arousal, amusement, and imaginary and sensory stimulation experienced by the consumer' (Boorsma, 2006: 79). 
A case study of museum visitors' experience (Chronis, 2012) has been chosen to exemplify this phenomenon. To accomplish the tourism experience of the customers/visitors, museums have to resolve a major challenge of offering an 'attractive link between heritage and tourism in a realistic reconstruction of the past in the present' (ibid.: 447). This can be achieved through the interpretation of museum visitors, whether through their perception of revelation of a higher truth or their understanding of a certain version of history different from the one being offered from the museum's point of view. Their participation encourages customers to become part of the emerged story and relate their own experience rather than staying as outside observers of the past. The tourism experience was characterized as a cycle with four stages: narrative familiarity, narrative enrichment, narrative imagining, and narrative closure.

The first stage starts when visitors enter the museum space. Their prior knowledge and experience related to the museum presentation will, accumulatively, form a narrative background. This helps them inform their interpretation of the museum experience and influence the way they process information. By being exposed to museum artefacts and other information sources, visitors enter the second phase, narrative enrichment. Whilst they may ignore some elements to selectively focus on some others as a part of the self-directed process, the ones they choose become pieces of the story with the potential to enrich the narrative of the past. The visitors start becoming story-builders to emerge in the museum environment whilst facing an exhibit with no easy explanation, trying to imagine the purpose and use of items exhibited, or placing them in a natural context such as a usual everyday situation. This activity of imagining narrative vignette has laid the foundation for the stage of narrative imagining. In the third stage, museum artefacts and other cultural resources are accounted as 'stage sets and props that spark visitors' imagination' (Chronis, 2012: 453) instead of being treated as isolated pieces of knowledge mentioned (Craig, 1989). The imagination of tourists, therefore, is used to elaborate on the integrated picture. By becoming a creative agent and activat- ing mechanism, the imagination evokes vicarious experiences and helps emotional understanding to 'provide coherence and realism to the narrative of the past' (Chronis, 2012: 451). When visitors put pieces of stories together, their narrative imaginative activity brings them a perception of the wholeness and enlivens the story. The narrative closure stage begins when visitors add their own moral closure besides imagination (Kashima, 1997), personally associate with the museum narrative, and connect with the museum story (Escalas and Stern, 2003) that creates empathy and engagement. In this stage, the unfolding narrative is seen from the tourists' perspective, which makes them a part of the narrative and strengthens their connection with 
the story of the past. It is noteworthy that the whole experience in the museum will add to the extant knowledge of visitors and enrich their narrative familiarity, making story-building an ongoing process with new opportunities for personal engagement and fulfilment.

The case study of museum visitors' experience has presented how the success of narrative presentation also depends on the customers instead of relying solely on the quality of the narrative itself or the marketers. Their involvement, willingness and ability to actively participate in the story-telling experience accumulatively create meaning for the services and open opportunities for the museum. This further illuminates the vital role of customers as the co-producers of meanings of cultural products and services.

\section{TYPOLOGIES OF CUSTOMERS IN CO-INNOVATION}

Rigorous research has been conducted to look at customer co-creation from many angles, ranging from the roles of customers in the NPD process to various types of value contributed by them. However, customers are heterogeneous, and thus identifying and profiling customers into distinct typologies is important in gaining insight and leveraging their competence in coinnovation. Since typology construction is both the result of and the vehicle for sense-making activity (Spiggle and Sanders, 1984), the benefit of understanding genres of customers is twofold. First, it helps us understand the complexity of co-innovation and the performance of the customers in value co-creation. Second, it facilitates our prediction and control of the behaviors of potential customers who will adopt a new product once it is commercialized in the marketplace. Therefore, this section will employ different criteria containing innovativeness, opinion leadership, involvement, motivation, and personality to comprehend four major approaches to customer typologies in co-innovation, namely lead user theory, expert users, user-innovators, and the trait-based approach. This discussion is expected to suggest a more integrative and comprehensive approach to identifying and analysing the right customers for co-innovation activities.

\section{Lead User}

The lead user could be counted as the first and most popular theory in the customer co-creation literature. Being recognized as having needs for solutions much greater than other users, they expect great benefits from finding solutions to improve the existing products and often come up with innovations more frequently than normal customers (Shin et al., 2012; Piller et al., 
2011; Von Hippel, 1986). Besides their innovativeness in ideas and concepts, they are notable for their opinion leadership. Also known as innovating users or market initiators (Lüthje, 2004), they are presumably the first to buy the products developed on the basis of their requests and ideas and are predisposed to discover novel functions or new ways of product use (Price and Ridgeway, 1983). In addition, lead users are competent in proposing commercially attractive solutions (Bosch- Sijitsema and Bosch, 2014) or ideas with strong potential to be commercialized in the market (Franke and Von Hippel, 2003; Lilien et al., 2002; Urban and von Hippel, 1988). However, there are a few gaps in the lead user theory to be addressed. First, this theory mainly receives attention in business-to-business settings (Hoffman et al., 2010; Schrerier et al., 2007), which makes it more difficult to identify lead users in the consumer market. Second, it is being questioned for being associated with certain domains of use (Hoffman et al., 2010), which has narrowed its application into some specific contexts. Consequently, the innovation literature has called for further research on customer genres that can be recruited for value cocreation. New approaches to identifying and profiling customers capable of developing new products in a widely applicable context are also of interest to marketing scholars.

\section{Expert Users}

This notion was introduced in 1995 to focus on users possessing product expertise. It was especially identified in developing high technology-based products since scholars emphasized that, in major innovations, only respondents with a high degree of expertise should be used for concept testing and idea generation (Schoormans et al., 1995). Customers, there- fore, will be identified for their knowledge, competence and skills beyond merely being the first people to possess a product. Findings also suggested that the involvement of users with domain knowledge is suitable in the ideation stage (Schweitzer et al., 2014; Hoyer et al., 2010), evaluations of new-product concepts, and the concept testing stage (De Bont and Schoormans, 1995). In more recent research, Schweitzer et al. argued that these groups of customers can be further classified as users with 'high ethical reflectiveness' besides 'high trend awareness', 'high technical skills' and 'high technical innovativeness' as ideas generated by each genre vary significantly in many quality dimensions (2014: 155). Their findings sup- ported the emergence of the value creation concept that recognizes that customers' contributions should go beyond creating a new product function or a technology-based innovation. Consequently, customers can be recruited for other attributes, such as their sociable skills, besides their domain knowledge and competence. 


\section{User-innovators}

Subsequent research of customers' roles in co-innovation suggested that customers can perform more active roles rather than being merely the helpers to producers (Bogers et al., 2010). To describe users who can innovate themselves, design for use and test for use, the notion of user-innovators has emerged (Baldwin et al., 2006). Evidence of user-innovators can be found in many studies since the 1960s in many sectors, from oil refining to chemical industry. Users started innovating themselves for a number of reasons, for instance, creating low-cost innovative solutions or gaining benefit from using innovation and selling innovation. Also, when they found it difficult to transfer information to producers due to the stickiness of information, they preferred to create a new product by themselves to better meet their needs. This also implied that customers with high creativity might not be opinion leaders or influencers in the market. In their description, user-innovators were clearly distinguished from user- purchasers, who hold opinion leadership and tend to be the first to move in innovation adoption (Baldwin et al., 2006). Compared to other notions introduced previously, this concept highlights the innovativeness and potential of individuals in more diverse contexts.

By adopting this broad approach, user-innovators could be further classified into distinct groups. In terms of resources and competence, they can be divided into 'intermediate users as innovators' and 'consumer users as innovators' (Bogers et al., 2010: 3). While the former group includes scientists, surgeons, or any subjects who use equipment and components from producers to produce goods and services (Oliveira and Von Hippel, 2009; Lee, 1996; Foxall and Tierney, 1984), the latter group typically comprises end customers that play a dominant role in the invention process and diffuse innovative ideas within their communities, typically in the field of sports-related consumer goods and other leisure- time activities (Raasch et al., 2008; Luthje et al., 2005; Franke and Shah, 2003). When looking at the benefit from using their new or improved products and services, user-innovators can be categorized into 'user as postimplementation adapter' and 'user as source of innovation-related knowledge' (Bogers et al., 2010: 8). The former takes place when users meet their needs through being helped by producers to adapt the product better. The latter, by contrast, focuses on the customer-active paradigm, integrating the users' entrepreneurial role as well as the commercial diffusion of innovation (Foxall and Tierney, 1984) or engaging customers as co-producers of the products (Vargo and Lusch, 2004). However, the user-innovator theory is still pervasive. 
Whilst customers can invent products for their own needs and for commercialization purpose, this does not guarantee that the knowledge of the innovation, especially tacit knowledge, can be transferred to other parties (Afuah, 2001; Ogawa, 1998). Studies on user-innovators are also debatable and still require further empirical research to examine the specific role of userinnovators in different phases of co-innovation.

\section{Trait-based Approach}

Different from the lead user approach, which is mainly applicable in business-to-business settings, the trait-based approach moves towards an application in the consumer goods industry. This approach focuses more on consumer innovativeness, innovative predisposition (Midgley and Dowling, 1993), and innate innovativeness (Hirschman, 1980), which has been found to correlate positively with personality traits (Steenkamp et al., 1999).

The extant literature has seen studies developed from the Big Five theory with five well-known personality traits, namely 'Openness to experience', 'Extraversion', 'Conscientiousness', 'Agreeableness', and 'Neuroticism', and has confirmed a positive relation between the userinnovators' traits and the successful completion in various NPD stages (Stock et al., 2014; Costa and McCrae, 1992). In their findings, Stock et al. suggested that customers with the 'Openness to experience' and 'Extraversion' trait are prone to coming up with new ideas; hence they are more likely to participate in the idea generation stage. On the other hand, people with 'Neuroticism' and 'Conscientiousness' will be helpful in the commercialization stage since they have such a strong motivation for success that they can be against any conventional measure or expectations set by outsiders.

The trait-based approach is also found in combination with other con- structs in extant studies. In their research, Hoffman et al. (2010) proposed that the right customers for developing a new product concept should have an 'emergent nature', which was described as the unique ability of customers to envision how product concepts might be further developed so that the final product can be 'successful in the mainstream marketplace' (ibid.: 855). This envisioning, according to researchers, arises from 'a unique constellation of personality traits and processing abilities', including openness to experience and ideas, reflection, ability to engage in an experiential and rational thinking style, verbal and visual processing styles, high level of creativity, and optimism. These attributes allow customers to engage in a synergistic process of idea generation, enhancement of the original concept, and logical analysis to refine and further 
develop concepts. Customers high in emergent nature are proven to be appropriate for concept development; however, a combination of an emergent nature and other unique capabilities of customers is decisive in identifying the most competent for distinct tasks.

It should be noticed that the broader approach to values and roles of customers will keep challenging researchers in identifying customers for value co-creation. This leads to a quest for further investigation into customer' innovative behaviours and more fine-grained personality traits. A more integrative and comprehensive research will be of interest to scholars who attempt to fully profile customers relevant for co-innovation activities.

\section{CONCLUSIONS AND PROSPECTS FOR FUTURE RESEARCH}

By employing content analysis corroborated by case studies, this chapter has illustrated four key observations and trends in the development of customer co-creation in NPD. First, it captures the history of NPD evolution that construes the root of customer co-creation in NPD and demonstrates a clear growth in the number of articles in leading journals over the past four decades. Second, it demonstrates how customer roles in co-innovation activities have evolved and how they have been broadened significantly across the time together with the apprehension of the importance of customer contribution in NPD. Third, this chapter highlights the complexity in constructing a commonly accepted definition of customer value. More importantly, it denotes a shift in paradigm of customer value, in which Utility and Cost (Sacrifice) values are increasingly moving towards Symbolic and Experiential offerings. This chapter also indicates that research on customer typologies continues to attract scholars. Furthermore, there is a need to develop more effective classifications to profile and identify customers for value co-creation. Greater attention has been paid to a psychographic and traitbased approach to extend the genres of customers for co-innovation purposes.

It should be noted that 588 articles used for content analysis in this chapter may not be exhaustive samples to describe all the trends of the customer co-creation phenomenon. However, they are representative samples of leading journals and still sufficiently support the construction of theories and the discussion on major streams of studies. Furthermore, the development of theory over four decades has moderated the share of criticism of customer competence in co-innovation, ascertained the application of this approach in exploring and explaining new perspectives of existing theories, and suggested future research avenues. 
The critical role of customers can be further explored in the creation of Symbolic and Experiential values. The predisposition of customers in individualized taste and choice is contended to suggest an emergence of new values or create extraordinary 'products' and experiences. Following this contention, it will be worthwhile to gain an understanding of customer roles in developing products of high social interaction, such as the arts market. Although the extant research has shown limited opportunities for customers to be the coproducers in the arts, a fresh mind in defining new types of values will challenge this existing approach and extend the potential of customers, especially in the arts that are culturally and socially embedded and widely known for a high audience engagement and experience. In a broader sense, this encourages future research to explore customer competence in contributing aesthetic values or developing high cultural products. A wider approach to customer values also opens up more opportunities to recognize and deploy customer knowledge and make sense of their life style and experiences. Moreover, the shift towards symbolic and experiential value in the near future may be navigated to a new stage, such as a convergence of values associated with the ladder of engagement.

As the research field continues to evolve and mature, more attributes to examine customer cocreation will need to be developed. With respect to customer typology construction, a traitbased approach will continue to be deployed to identify and profile suitable customers for various types of value creation. Stemming from the philosophy of human actions based on sensibility, understanding and reasoning, studies on personalities may remain attractive to researchers. Furthermore, the psychographics approach, with a high focus on opinions and attitudes (Arts et al., 2011), may suggest new tactics to define early contributors to the innovative offerings and construct genres based on their notions of innovation. Researchers can also extend this application in gaining knowledge about customers' innovation expectations, adoption behaviour, value creation, and new factors that motivate them to cocreate new values and products. Advancing psychometrics in co-innovation activities can be meaningful for leveraging customer competence and inputs during their co-creation journey, as a means to increase the initial success of the innovation. For instance, as customers are more connected and influenced by their social circles, companies preparing for product innovation should recognize the importance of time and space in exchanging ideas and values and the innovative tribes they are invited in. Therefore, employment of the psychographics lens can spark even more research directions on customer co-creation. 
Being perceived as an emerging and fast-moving concept, customer value co-creation deserves continuous study and attention from both researchers and practitioners. There is a clear need for further empirical research, a larger scale of studies, and broader examinations of this phenomenon. More attributes of examination and cross-disciplinary research are expected to produce a wide range of benefits for the research field, from challenging the established concepts, stimulating new ways of thinking, to adding new value for products. These suggestions are expected to provide the compass for future research attempts to further advance the customer co-creation in NPD literature.

\section{REFERENCES}

Aburdene, P. (2005). Mega-trends 2010: The Rise of Conscious Capitalism. Charlottesville, VA: Hampton Roads.

Adams, R., Bessant, J. and Phelps, R. (2006). Innovation management measurement: A review. International Journal of Management Reviews, 8(1), 21-47.

Afuah, A. (2001). Dynamic boundaries of the firm: Are firms better off being vertically integrated in the face of a technological change? Academy of Management Journal, 44(6), 1211-28.

Armstrong, A., \& Hagel, J. (1997). Net gain: Expanding markets through virtual communities. Harvard Business School.

Arts, J.W., Frambach, R.T. and Bijmolt, T.H. (2011). Generalizations on consumer innovation adoption: A meta-analysis on drivers of intention and behavior. International Journal of Research in Marketing, 28(2), 134 44.

Baldwin, C., Hienerth, C. and Von Hippel, E. (2006). How user innovations become commercial products: A theoretical investigation and case study. Research Policy, 35(9), 1291-313.

Baregheh, A., Rowley, J. and Sambrook, S. (2009). Towards a multidisciplinary definition of innovation. Management Decision, 47(8), 1323-39.

Berg, B.L. (2004). Qualitative Research Methods for the Social Sciences. Boston, MA: Pearson Education.

Bogers, M., Afuah, A. and Bastian, B. (2010). Users as innovators: A review, critique, and future research directions. Journal of Management, 36(4), 857-75.

Boorsma, M. (2006). A strategic logic for arts marketing: Integrating customer value and artistic objectives. International Journal of Cultural Policy, 12(1), 73-92.

Bosch-Sijtsema, P. and Bosch, J. (2014). User involvement throughout the innovation process in high-tech industries. Journal of Product Innovation Management, 32(5), 793-807. 
Brown, S. (2007). Harry Potter and the fandom menace. In B. Cova, R.V. Kozinets and A. Shankar (eds), Consumer Tribes, London: Butterworth-Heinemann, pp. 177-91.

Bryman, A. (2001). Social Research Method. Oxford: Oxford University Press.

Butz, H. and Goodstein, L. (1996). Measuring customer value: Gaining the strategic advantage. Organizational Dynamics, 24(Winter), 63-77.

Cavanagh, S. (1997). Content analysis: Concepts, methods and applications. Nurse Researcher, 4(3), 5-13. Chesbrough, H. (2003). The logic of open innovation: Managing intellectual property. California Management Review, 45(3), 33-58.

Chronis, A. (2012). Tourists as story-builders: Narrative construction at a heritage museum. Journal of Travel \& Tourism Marketing, 29(5), 444-59.

Constantinides, E., Brünink, L.A. and Lorenzo-Romero, C. (2015). Customer motives and benefits for participating in online co-creation activities. International Journal of Internet Marketing and Advertising, 9(1), $21-48$.

Costa, P.T. and McCrae, R.R. (1992). Four ways five factors are basic. Personality and Individual Differences, 13(6), 653-65.

Craig, B. (1989). Interpreting the historic scene: The power of imagination in creating a sense of historic place. In D.L. Uzzell (ed.), Heritage Interpretation. London: Belhaven Press, pp. 107-12.

Darroch, J. and McNaughton, R. (2002). Examining the link between knowledge management practices and types of innovation. Journal of Intellectual Capital, 3(3), 210-22.

Dash, R. (2013). Market segmentation of Facebook users. IIM Bangalore Research Paper, (438).

De Bont, C.J.P.M. and Schoormans, J.P.L. (1995). The effects of product expertise on con- sumer evaluations of new-product concepts. Journal of Economic Psychology, 16, 599-615. Dey, A.K. (2010). Mass customization and beyond: Application of co-creation \& postponement. SSRN Working Paper Series.

Downe-Wamboldt, B. (1992). Content analysis: Method, applications, and issues. Health Care for Women International, 13(3), 313-21.

Escalas, J.E. and Stern, B.B. (2003). Sympathy and empathy: Emotional responses to advertising dramas. Journal of Consumer Research, 29, 566-78.

Foray, D. (2004). New models of innovation and the role of information technologies in the knowledge economy. In W. Dutton, B. Kahin, R. O'Callaghan and A. Wyckoff (eds), Transforming Enterprise, the Economic and Social Implications of Information Technology. Cambridge, MA: MIT Press, pp. 113-30.

Foxall, G.R. and Tierney, J.D. (1984). From CAP1 to CAP2: User-initiated innovation from the user's point of view. Management Decision, 22(5), 3-15.

Franke, N. and Shah, S. (2003). How communities support innovative activities: An exploration of assistance and sharing among end-users.

Research Policy, 32(1), 157-78. Franke, N. and Von Hippel, E. (2003). Satisfying heterogeneous user needs via innovation toolkits: The case of Apache security software. Research Policy, 32(7), 1199-215. 
Füller, J., Jawecki, G. and Mühlbacher, H. (2007). Innovation creation by online basketball communities. Journal of Business Research, 60(1), 60-71.

Füller, J., Bartl, M., Ernst, H. and Mühlbacher, H. (2006). Community based innovation: How to integrate members of virtual communities into new product development. Electronic Commerce Research, 6(1), 57-73.

Gale, B.T. (1994). Managing Customer Value. New York: Free Press.

Garcia, R. and Calantone, R. (2001). A critical look at technological innovation typology and innovativeness terminology: A literature review. The Journal of Product Innovation Management, 19, 110-32.

Gardial, S.F., Scott Clemons, D., Woodruff, R.B., Schumann, D.W. and Burns, M.J. (1994). Comparing consumers recall of prepurchase and postpurchase product evaluation experiences. Journal of Consumer Research, 20, 548-60.

Goulding, C. and Saren, M. (2010). Immersion, emergence and reflexivity: Grounded theory and aesthetic consumption. International Journal of Culture, Tourism and Hospitality Research, 4(1), 70-82.

Graf, A. (2007). Changing roles of customers: Consequences for HRM. International Journal of Service Industry Management, 18(5), 491-509.

Heard, E. (1993). Walking the talk of customer value. National Productivity Review, 13(1), 21-7.

Hetet, B., Moutot, J-M. and Mathieu, J-P. (2014). A better understanding of consumer's perception of an innovative brand through perceived novelty. Accessed at http://www. marketing-trendscongress.com/archives/2014/pages/PDF/245.pdf.

Hirschman, E.C. (1980). Innovativeness, novelty seeking, and consumer creativity. Journal of Consumer Research, 7(3), 283-95.

Hoffman, D.L., Kopalle, P.K. and Novak, T.P. (2010). The "right" consumers for better concepts: Identifying and using consumers high in emergent nature to further develop new product concepts. Journal of Marketing Research, 47(5), 854-65.

Holbrook, M.B. (2005). Customer value and autoethnography: Subjective personal introspection and the meanings of a photograph collection. Journal of Business Research, 58(1), 45-61.

Holbrook, M.B. (1999). Consumer Value: A Framework for Analysis and Research. London: Routledge.

Holbrook, M.B. and Hirschman, E.C. (1982). The experiential aspects of consumption: Consumer fantasies, feelings, and fun. Journal of Consumer Research, 9(2), 132-40.

Hoyer, W.D., Chandy, R., Dorotic, M., Krafft, M. and Singh, S.S. (2010). Consumer cocreation in new product development. Journal of Service Research, 13(3), 283-96.

Kashima, Y. (1997). Culture, narrative, and human motivation. In D. Munro, J.F. Schumaker and S.C. Carr (eds), Motivation and Culture. New York: Routledge, pp. 16-30. 
Khurana, A. and Rosenthal, S.R. (1998). Towards holistic "front ends" in new product development. Journal of Product Innovation Management, 15(1), 57-74.

Krippendorff, K. (1980). Content Analysis: An Introduction to its Methodology. Newbury Park, CA: Sage.

Lee, K.R. (1996). The role of user firms in the innovation of machine tools: The Japanese case. Research Policy, 25, 491-507.

Lee, S.M., Olson, D.L. and Trimi, S. (2012). Co-innovation: Convergenomics, collaboration, and co-creation for organizational values. Management Decision, 50(5), 817-31.

Li, T. and Calantone, R.J. (1998). The impact of market knowledge competence on new product advantage: Conceptualization and empirical examination. The Journal of Marketing, 62(4), 13-29.

Lichtenthaler, U., Hoegl, M. and Muethel, M. (2011). Is your company ready for open innovation? MIT Sloan Management Review, Fall, pp. 45-8.

Lilien, G.L., Morrison, P.D., Searls, K., Sonnack, M. and Von Hippel, E. (2002). Performance assessment of the lead user idea-generation process for new product development. Management Science, 48(8), 1042-59.

Loic, P., Lecocq, X. and Angot, J. (2010). Customer-integrated business models: A theoretical framework. Management, 13(4), 226-65.

Lüthje, C. (2004). Characteristics of innovating users in a consumer goods field: An empirical study of sportrelated product consumers. Technovation, 24(9), 683-95.

Lüthje, C., Herstatt, C. and Von Hippel, E. (2005). User-innovators and "local” information: The case of mountain biking. Research Policy, 34(6), 951-65.

Magnusson, P.R. (2003). Benefits of involving users in service innovation. European Journal of Innovation Management, 6(4), 228-38.

Mele, C., Colurcio, M. and Russo-Spena, T. (2009). Alternative logics for innovation: A call for service innovation research. In Proceedings of the Naples Forum on Service Conference, 16-19 June, Capri.

Midgley, D.F. and Dowling, G.R. (1993). A longitudinal study of product form innovation: The interaction between predispositions and social messages. Journal of Consumer Research, 19(4), 611-25.

Mukhtar, M., Ismail, M.N. and Yahya, Y. (2012). A hierarchical classification of co-creation models and techniques to aid in product or service design. Computers in Industry, 63(4), 289-97.

Muniz, A.M. and O’Guinn, T.C. (2001). Brand community. Journal of Consumer Research, 27, 412-32.

Nambisan, S. and Baron, R.A. (2007). Interactions in virtual customer environments: Implications for product support and customer relationship management. Journal of Interactive Marketing, 21(2), 42-62.

Närvänen, E. (2013). Extending the Collective Consumption of Brands. Ph.D. thesis, University of Finland.

Ogawa, S. (1998). Does sticky information affect the locus of innovation? Evidence from the Japanese convenience store industry. Research Policy, 26, 777-90.

O’Hern, M. and Rindfleisch, A. (2010). Customer co-creation. Review of Marketing Research, 6, 84-116. 
Oliveira, P. and Von Hippel, E. (2009). Users as service innovators: The case of banking services. Working paper no. 4748-09, MIT Sloan School of Management.

O'Shaughnessy, J. and O'Shaughnessy, N.J. (2009). The service-dominant perspective: A backward step? European Journal of Marketing, 43(5/6), 784-93.

O'Shaughnessy, J. and O'Shaughnessy, N.J. (2011). Service-dominant logic: A rejoinder to Lusch and Vargo's reply. European Journal of Marketing, 45(7/8), 1310-18.

Page, A.L. and Schirr, G.R. (2008). Growth and development of a body of knowledge: 16 years of new product development research, 1989-2004. Journal of Product Innovation Management, 25(3), 233-48.

Pals, N., Steen, M.G., Langley, D.J. and Kort, J. (2008). Three approaches to take the user perspective into account during new product design. International Journal of Innovation Management, 12(03), 275-94.

Parasuraman, A. (1997). Reflections on gaining competitive advantage through customer value. Journal of the Academy of Marketing Science, 25(2), 154-61.

Park, C.W., Jaworski, B. and MacInnis, D. (1986). Strategic brand concept-image management. Journal of Marketing, 50(October), 135-45.

Peñaloza, L. and Venkatesh, A. (2006). Further evolving the new dominant logic of market- ing: from services to the social construction of markets. Marketing Theory, 6(3), 299-316.

Prahalad, C.K. and Ramaswamy, V. (2004). Co-creation experiences: The next practice in value creation. Journal of Interactive Marketing, 18(3), 5-14.

Piller, F.T. and Lindgens, E. (2011). Customer co-creation: Moving beyond market research to reduce the risk in new product development. In L. Horne (ed.), New Product Development in Textiles: Innovation and Production, Cambridge: Woodhead Publishing, pp. 175-89.

Piller, F., Ihl, C. and Vossen, A. (2011). Customer co-creation: Open innovation with customers. In V. Wittke and H. Hanekop (eds), New Forms of Collaborative Innovation and Production on the Internet, Göttingen: Universitätsverlag Göttingen, pp. 31-63.

Pine, B.J. and Gilmore, J.H. (1999). The Experience Economy: Work is Theatre \& Every Business a Stage. Boston, MA: Harvard Business Press.

Price, L.L. and Ridgway, N.M. (1983). Development of a scale to measure use innovativeness. Advances in Consumer Research, 10(1), 679-84.

Raasch, C., Herstatt, C. and Lock, P. (2008). The dynamics of user innovation: Drivers and impediments of innovation activities. International Journal of Innovation Management, 12, 377-98.

Ramirez, R. (1999). Value co-production: Intellectual origins and implications for practice and research. Strategic Management Journal, 20(1), 49-65.

Romero, D. and Molina, A. (2011). Collaborative networked organisations and customer communities: Value co-creation and co-innovation in the networking era. Production Planning \& Control, 22(5-6), 447-72.

Rothwell, R. (1976). Innovation in textile machinery: Some significant factors in success and failure. Science Policy Research Unit, University of Sussex.

Sandelowski, M. (1995). Qualitative analysis: What it is and how to begin. Research in Nursing \& Health, 18, $371-5$. 
Schoormans, J.P.L., Ortt, R.J. and De Bont, C.J.P.M. (1995). Enhancing concept test validity by using expert consumers. Journal of Product Innovation Management, 12, 153-62.

Schreier, M., Oberhauser, S. and Prügl, R. (2007). Lead users and the adoption and diffusion of new products: Insights from two extreme sports communities. Marketing Letters, 18(1-2), 15-30.

Schubert, P. and Ginsburg, M., (2000). Virtual communities of transaction: The role of personalisation in electronic commerce. Electronic Markets, 10(1), 45-55.

Schweitzer, F., Gassmann, O. and Rau, C. (2014). Lessons from ideation: Where does user involvement lead us? Creativity and Innovation Management, 23(2), 155-67.

Shin, D.H., Jung, J. and Chang, B.H. (2012). The psychology behind QR codes: User experience perspective. Computers in Human Behavior, 28(4), 1417-26.

Sinha, Indrajit and DeSarbo, Wayne (1998). An integrated approach toward the spatial modeling of perceived customer value. Journal of Marketing Research, 35(2), 236-49.

Smith, J.B. and Colgate, M. (2007). Customer value creation: A practical framework. Journal of Marketing Theory and Practice, 15(1), 7-23.

Spiggle, S. and Sanders, C.R. (1984). The construction of consumer typologies: Scientific and ethnomethods. Advances in Consumer Research, 11(1).

Steenkamp, J.B.E.M., ter Hofstede, F. and Wedel, M. (1999). A cross-national investigation into the individual and national cultural antecedents of consumer innovativeness. Journal of Marketing, 63(2), 55-69.

Stemler, S. (2001). An overview of content analysis. Practical Assessment, Research \& Evaluation, 7(17), 13746.

Stock, Ruth M., Von Hippel, Eric A. and Schnarr, L. (2014). Impacts of personality traits on user innovation success. MIT SSM working paper. Available at http://papers.ssrn.com/sol3/papers.cfm?abstract_id52467152

Thomke, S. and Von Hippel, E. (2002). Customers as innovators: A new way to create value. Harvard Business Review, 80(4), 74-81.

Tran, M.K and Shiu, E. (2015). User-innovator typologies in co-innovation: From creativity to reality. Proceedings of ISPIM 2015, the Twenty-sixth International Conference on Innovation Management, Budapest, Hungary, 14-17 June. Elsevier Science.

Ulaga, Wolfgang (2003). Capturing value creation in business relationships: A customer perspective. Industrial Marketing Management, 32(8), 677-93.

Urban, G.L. and Von Hippel, E. (1988). Lead user analyses for the development of new industrial products. Management Science, 34(5), 569-82.

U.S. General Accounting Office (1996). Content Analysis: A Methodology for Structuring and Analyzing Written Material. Washington, DC: GAO/PEMD-10.3.1 (this book can be ordered free from the GAO). 
Vandecasteele, Bert and Geuens, Maggie (2010). Motivated consumer innovativeness: Concept, measurement, and validation. International Journal of Research in Marketing, 27(4), 308-18.

Van Gennep, A. (1960 [2004]). The Rites of Passage. London: Routledge.

Vargo, S.L. and Lusch, R.F. (2004). Evolving to a new dominant logic for marketing. Journal of Marketing, 68(1), 1-17.

Vargo, S.L. and Lusch, R.F. (2008). Service-dominant logic: Continuing the evolution. Journal of the Academy of Marketing Science, 36(1), 1-10.

Von Hippel, E. (1986). Lead users: A source of novel product concepts. Management Science, 32(7), 791-805. Von Hippel, E., Thomke, S. and Sonnack, M. (1999). Creating breakthroughs at 3M. Harvard Business Review, 77, 47-57.

Von Krogh, G. (2006). The HBR list: Breakthrough ideas for 2006. In H. Tran (ed.) Harvard Business Review. DOI: $10.1225 / \mathrm{R} 0602 \mathrm{~B}$.

Weber, R.P. (1990). Basic Content Analysis. Newbury Park, CA: Sage Publications.

Whelan, E., Parise, S., De Valk, J. and Aalbers, R. (2011). Creating employee networks that deliver open innovation. MIT Sloan Management Review, Fall, 37-44.

Wijnberg, N.M. (2004). Innovation and organization: Value and competition in selection systems. Organization Studies, 25(8), 1413-33.

Woodall, Tony (2003). Conceptualization "value for the customer": An attributional, structural and dispositional analysis. Academy of Marketing Science Review, 12.

Woodruff, Robert (1997). Customer value: The next source for competitive advantage. Journal of the Academy of Marketing Science, 25(2), 139-53.

Zare Bidaki, S. (2015). What motivators and inhibitors to co-creation are deemed important for tailored cocreators? Study of consumer characteristics on co-creation for three different products. Graduation thesis. Available at https://www.politesi.polimi.it/bit stream/10589/108053/1/Thesis\%20Shahab\%20Zare.pdf.

Zeithaml, Valarie (1988). Consumer perceptions of price, quality, and value: A means-end model and synthesis of evidence. Journal of Marketing, 52(July), 2-22.

Zhang, Q. and Doll, W.J. (2001). The fuzzy front end and success of new product development: A causal model. European Journal of Innovation Management, 4(2), 95-112. 